\title{
The perceptions of students and instructor in a graduate mathematical modeling class:
}

\section{An experience with remote education}

\author{
A percepção de alunos e professor em uma disciplina de modelagem matemática em uma pós- \\ graduação: Uma experiência de educação à distância \\ La percepción de estudiantes y professor em uma disciplina de modelado matemático en uma pós- \\ graduación: Uma experiencia de educación a distancia
}

Received: 04/19/2021 | Reviewed: 04/27/2021 | Accept: 05/05/2021 | Published: 05/19/2021

Tales Alexandre Aversi-Ferreira ORCID: https://orcid.org/0000-0002-4417-7209 Universidade Federal de Alfenas, Brazil E-mail: tales.ferreira@unifal-mg.edu.br

Karolyne Cordeiro de Oliveira ORCID: https://orcid.org/0000-0002-6256-1968 Universidade Federal de Alfenas, Brazil E-mail: karolyne.cordeiro@sou.unifal-mg.edu.br Samuel Vitor Assis Machado de Lima ORCID: https://orcid.org/0000-0003-0167-9804 Universidade Federal de Alfenas, Brazil

E-mail: samuel.lima@sou.unifal-mg.edu.br Wellington Felipe dos Santos ORCID: https://orcid.org/0000-0002-2297-6536 Universidade Federal de Alfenas, Brazil E-mail: wellington.santos@sou.unifal-mg.edu.br

Carla Aparecida Costa

ORCID: https://orcid.org/0000-0001-6458-7750 Universidade Federal de Alfenas, Brazil

E-mail: carla.costa@sou.unifal-mg.edu.br

Evelyn Bastos Resende

ORCID: https://orcid.org/0000-0003-4944-5820 Universidade Federal de Alfenas, Brazil

E-mail: evelyn.resende@ sou.unifal-mg.edu.br

Julia Soares de Moraes Siqueira

ORCID: https://orcid.org/0000-0002-3932-1392 Universidade Federal de Alfenas, Brazil

E-mail: julia.siqueira@sou.unifal-mg.edu.br Janaína Piza Ferreira

ORCID: https://orcid.org/0000-0002-2429-4352 Universidade Federal de Alfenas, Brazil

E-mail: janaina.piza@sou.unifal-mg.edu.br

Juliana Mafra Salgado Andrade ORCID: https://orcid.org/0000-0002-5265-7819 Universidade Federal de Alfenas, Brazil

E-mail: juliana.salgado@sou.unifal-mg.edu.br

\begin{abstract}
Difficulties with adequately teaching mathematics is a challenge not yet overcome by teachers. It is an important subject that directly involves educators and teachers, and indirectly society. New proposals for teaching mathematics have not been completely implemented and must be tested among the many levels of student life. One possibility for bringing teachers in accord with new teaching strategies is by pedagogical development, such as attending specific courses for teaching, to at least become aware of new methodologies and to learn how to apply them. The purpose of this work was to analyze the use of the Mathematical Modeling methodology in a course offered in a graduate Environmental Sciences curriculum using the active methodologies. The aim was to assess the development of cognitive abilities, favoring reflection and questioning into mathematical modeling, that occurred during remote teaching due to the pandemic. A structured questionnaire was given to students and the responses were used to interpretate their perception of the discipline/course and active methodology
\end{abstract}


proposed. The problems cited by other authors, such as limited time and a culture engrained in traditional teaching, were observed by the present study, indicating the need in to introduce mathematical modeling and problem solving in the initial phases of teaching mathematics.

Keywords: Active methodology; New technologies for teaching; Mathematical modeling; Graduate teaching.

\section{Resumo}

A dificuldade em ensinar matemática de forma adequada é um desafio ainda não superado pelos professores. É um assunto importante que envolve diretamente educadores e professores, e indiretamente a sociedade. As novas propostas para o ensino da matemática não foram totalmente implementadas e devem ser testadas nos diversos níveis de vida do aluno. Uma possibilidade de aproximar os professores de novas estratégias de ensino é por meio do desenvolvimento pedagógico, como frequentar cursos específicos para a docência, para, pelo menos conhecerem novas metodologias e aprender a aplicá-las. O objetivo deste trabalho foi analisar a utilização da metodologia de Modelagem Matemática em um curso oferecido em um currículo de graduação em Ciências Ambientais utilizando as metodologias ativas. O objetivo foi avaliar o desenvolvimento das habilidades cognitivas dos estudantes, favorecendo a reflexão e o questionamento na modelagem matemática, ocorrida durante o ensino a distância em decorrência da pandemia. Foi aplicado um questionário estruturado aos alunos e as respostas foram utilizadas para interpretar suas percepções sobre a disciplina/curso e a metodologia ativa proposta. Os problemas citados por outros autores, como o tempo limitado e uma cultura arraigada no ensino tradicional foram observados no presente estudo, indicando a necessidade de se introduzir a modelagem matemática e a resolução de problemas nas fases iniciais do ensino da matemática.

Palavras-chave: Metodologia ativa; Novas tecnologias de ensino; Modelagem matemática; Ensino de pós-graduação.

\section{Resumen}

Las dificultades para la enseñanza adecuada de las matemáticas es un desafío que los profesores aún no han superado. Es un tema importante que involucra directamente a educadores y profesores, e indirectamente a la sociedad. Las nuevas propuestas para la enseñanza de las matemáticas no se han implementado completamente y deben ser probadas entre los muchos niveles de la vida estudiantil. Una posibilidad para acercar a los docentes a las nuevas estrategias de enseñanza es mediante el desarrollo pedagógico, como la asistencia a cursos específicos de docencia, para al menos tomar conciencia de nuevas metodologías y aprender a aplicarlas. El propósito de este trabajo fue analizar el uso de la metodología de Modelado Matemático en un curso ofrecido en un plan de estudios de posgrado en Ciencias Ambientales utilizando las metodologías activas. El objetivo fue evaluar el desarrollo de las habilidades cognitivas, favoreciendo la reflexión y el cuestionamiento en modelos matemáticos, que ocurrieron durante la enseñanza a distancia debido a la pandemia. Se entregó un cuestionario estructurado a los estudiantes y las respuestas se utilizaron para interpretar su percepción de la disciplina/curso y la metodología activa propuesta. Los problemas citados por otros autores, como el tiempo limitado y una cultura arraigada en la enseñanza tradicional, fueron observados por el presente estudio, lo que indica la necesidad de introducir modelos matemáticos y resolución de problemas en las fases iniciales de la enseñanza de las matemáticas.

Palabras clave: Metodología activa; Nuevas tecnologías de enseñanza; Modelización matemática; Docencia de posgrado.

\section{Introduction}

\subsection{Some comments about mathematics education}

Educational teaching methods have been studied by mathematicians for a long time (Alves \& Aversi-Ferreira, 2019) and used by other exact and un-exact fields, sometimes because of the few, or lack of, didactic studies in such areas.

Problems concerning mathematical education led researchers of pedagogy to search the ancient philosophical conceptions of Plato, Aristoteles, Kant and/or Descartes (Machado, 1987; Piaget \& Beth, 1980), as bases for new educational technologies for problem solving, mathematical modeling and teaching of the history of mathematics (D’Ambrósio, 2008) since the Middle Ages, which were modernly tested in practical teaching (D’Ambrósio, 1998; Biembengut, 2014). Indeed, the study of classic works can generate an understanding of the reasons behind modern methods of education (Nosella, 2004).

Specifically, both approaches to the new purpose for teaching mathematics — problem solving and mathematical modeling — are intimately linked because the solution of a problem must use the creation of a model in the language of math (Faccin, 2015).

For instance, according with history the problem solving seems to be an innate part of human nature (Caon \& Cardona, 2015; Rodrigues \& Magalhães, 2012) as demonstrated by the history of the Chinese, Egyptians and Greeks (Stanic \& Kilpatrick; 
Research, Society and Development, v. 10, n. 6, e2310615223, 2021

(CC BY 4.0) | ISSN 2525-3409 | DOI: http://dx.doi.org/10.33448/rsd-v10i6.15223

1989), and observed in the Hind Papyrus, Moscow Papirus (Ravagnani \& Marques, 2017) and trigonometric problems in the clay tablet known as Plimpton 322 produced by Babylonians (Mansfield \& Widberg, 2017).

From the Greeks we obtained the heritage of the heuristic steps for problem solving that is still used today (Groenwald, Silva \& Mora, 2004), namely: (1) task, (2) indication, (3) thesis, (4) construction, (5) demonstration and (6) conclusion, following this reasoning, over history mathematics became the basis for exact sciences, collaborating, inter alia, with language, descriptive analysis, modeling and simulation, thereby providing tools for more trustworthy projects (Onuchic, 2013).

However, it is important to separate the epistemology of mathematical sciences from mathematical education, because the latter is not an exact science but instead is empirical and multidisciplinary with a more social and pedagogical objective - i.e., to generate a path for the student to learn (Onuchic, 2013).

Among studies of mathematical education came a proposal to teach mathematics using modern methodologies, in an effort to use mathematics pedagogy as a tool to generate proper knowledge for different students (Onuchic, 2013). A historical view reveals the long time that educational researchers have studied changes in mathematics teaching, although conservatism in education has prevailed until now, putatively because of the difficulty in changing ingrained behaviors (Alves \& Aversi-Ferreira, 2019).

Indeed, a common and hodiern problem is that despite research and reflections about teaching mathematics, new methodologies in mathematical education are not yet frequently and satisfactorily applied in classes, while traditional principles still remain, at least in Brazil (Groenwald, Silva \& Mora, 2004; Rodrigues \& Magalhães, 2012). In fact, new methodologies are scarcely used in teaching (Groenwald, Silva \& Mora, 2004); in many countries this situation has converged on the same points. Nonetheless, topics to modify this situation have been proposed for teaching, such as the use of (1) problem resolution; (2) quotidian mathematics; and (3) math problems found in other disciplines. These ideas are also cited by the National Curricular Parameters in Brazil (Brasil, 1998).

Furthermore, the purpose of mathematical education is, in the context of students, to promote the use the critical thinking (Lupinacci \& Botin, 2004), with the objectives of (1) improving methods of investigation; (2) developing complex thinking processes; and (3) catenation of ideas using math and logical procedures, generating, at least, critical thinking for the comprehension of hypothesis formulation and generalization (Groenwald, Silva \& Mora, 2004).

These are proposals for students to become the author of their own knowledge, which is the basis of active methodologies different form the traditional methods (Utsumi, 2020). In this way, for instance, the new proposals do not match the use of long lists of exercises (Ferreira, Silva \& Nunes, 2015), as preconized by the method of mental discipline theory (Groenwald, Silva \& Mora, 2004), that is still usual nowadays, but based on a conservative teaching that is far from the needs of modern society (Ferraz, 1983).

Many methodologies in mathematics education are unknown by most educators (Groenwald, Silva \& Mora, 2004) and students. In fact, these methodologies are difficult for teachers of math and correlated fields (Alves \& Aversi-Ferreira, 2019) to understand efficiently (Stanic \& Kilpatrick,1989), which makes the expanse of these methodologies difficult.

It is widely known that most students experience difficulty with learning mathematics in the classroom because, inter alia, and perhaps, the lack of interest or accommodation of pupils since primary (elementary or fundamental) school. This aspect also depends on the demotivation of teachers (Prediger, Berwanger \& Mörs; 2009), because passivity of encouragement demotivates others and vice versa (Alves \& Aversi-Ferreira, 2019).

From the perspective of new methodologies, problems presented to students must be as challenging as possible and real to generate interest (with an unknown perspective to motivate, and not only the application of an algorithm) and present some level of difficulty (Dante, 1998) to avoid demotivation (Rodrigues \& Magalhães, 2012). The enthusiasm of pupils is also dependent on that 
Research, Society and Development, v. 10, n. 6, e2310615223, 2021

(CC BY 4.0) | ISSN 2525-3409 | DOI: http://dx.doi.org/10.33448/rsd-v10i6.15223

of the teacher and of the teacher/student relationship (Lupinacci \& Botin, 2004), for teachers gain positive feedback. Indeed, this is a complex subject that needs deep investigation by educators. Accordingly, new methodologies for education play a very important role in new approaches to teaching, generating a new perspective for learning, in general, and for mathematics teaching (Alves \& Aversi-Ferreira, 2019).

A highly studied purpose of the new mathematical methodology is problem solving, which indicates to students a new routine and stimulates thinking, with emphasis on the process, generating situations that require reasoning to solve problems by themselves (Lupinacci \& Botin, 2004; Caon \& Cardona, 2015). This increases an elaborate process of thinking (Ferreira, Silva \& Nunes, 2015) involving the application of deductive and inductive reasoning, for improved notions of graphic proportions, improving the capabilities to build conjectures and mathematical arguments, following logical arguments, and to validate their own construction (Mendes, 2009).

Different than conservative teaching, formulas are not the only true way to solve problems (Carraher, 1986; Caon \& Cardona, 2015); it is important to stimulate students to use procedures and previous knowledge to analyze formulas and real situations using critical thinking (Lupinacci \& Botin, 2004), which generates self-confidence, — which is a heuristic and not only mechanical process (Caon \& Cardona, 2015).

In these contexts, it is of educational interest to determine whether students leave courses, including university courses, adequately and efficiently prepared to face the market and graduate education, and whether they need to attend continuous education (Cintra \& Oliveira, 2001). Indeed, some professions need specific disciplines to improve their competences, both in labor and academia.

As cited above, academic works have indicated which didactic methods for teaching mathematical disciplines fail the purpose of education (Cintra \& Oliveira, 2001). Studies of how to teach those disciplines at a superior level are scarce or are at an incipient stage (Burak \& Kluber, 2008) for the undergraduate level, at least compared to the material dedicated to the same subject for elementary and high schools (Alves \& Aversi-Ferreira, 2019).

Nevertheless, it would be difficult to implement new methodologies for teaching at universities but attempts to use real problems associated with studies of scientific papers are an example that would maintain student attention by more time in classes (Ferreira, Silva \& Nunes, 2015) and could be more interesting to study.

It is also dependent on serious teacher training but, in general, teachers imitate their past teachers (Lima \& Alves Neto, 2015), especially new teachers, maybe because of insecurity (Smaniotto \& Gentil, 2014). Many teachers at universities, at both undergraduate and graduate levels, do not possess previous didactic preparation for teaching, which is a very important problem, especially for teaching mathematics and correlated disciplines (Alves \& Aversi-Ferreira, 2019).

From this perspective, this kind of teacher could maintain the tendency of continued past conservatism and, by deduction, the non-integration of student behavior in a constant changing world (Lester \& Koehler, 2003; Lesh \& Zawojewski, 2007), with this integration being one of the objectives of new methodologies for education.

It is reasonable to think that such problems are a heritage from elementary school to undergraduate and graduate education, in this way, the teachers were students and pass by the same educational structure (Massa, 2015), therefore, seems to be difficult for them to get out from this system of education. On the other hand, there are currently many possibilities for teaching differently than conservatism by new methodologies, such as the methods of mathematical modeling. If deep care is needed to teach math to pupils that are attracted to the exact sciences, teaching disciplines linked to mathematics for students of non-exact courses must also be done with great care and with very good preparation of the teacher to prevent disappointing students with math. 
Research, Society and Development, v. 10, n. 6, e2310615223, 2021

(CC BY 4.0) | ISSN 2525-3409 | DOI: http://dx.doi.org/10.33448/rsd-v10i6.15223

Adequate teaching requires good class preparation, discipline and organization (Ferreira, Silva, Nunes, 2015). For more pedagogical details about this subject see Allevato and Onuchic (2009), and Felder and Silverman (1988) for techniques on how to reach all types of students. On the other hand, teaching practices are not easy and require knowledge, abilities to maintain good relationships with students, anticipation of unknown reactions (Lima \& Alves Neto, 2015) and avoidance of being just a communicator (Godoy, 1983), according to new teaching purposes.

Higher education in Brazil generally has a technical and mechanical approach to teaching that is inconsistent with modern society (Alves \& Aversi-Ferreira, 2019, Moraes \& Torres, 2004) and the necessity of developing multiple abilities in individuals, such working as part of a team and the ability to adapt to changes (Belloni, 2008).

Teaching in higher education often requires a master and a doctorate, however, a didactic preparation could be also required (Fernandes, 1998). This is because graduate programs do not necessarily prepare teachers (Garcia, 2013) of undergraduate courses, or pedagogical courses provide insufficient preparation (Onuchic, 2013) in.

Indeed, there are many papers versa about mathematical teaching for elementary and secondary education, including problem solving, for instance (Lupinacci \& Botin, 2004; Chiréia, 2010; Clement \& Terrazan, 2011; Silva, 2012; Caon \& Cardona, 2015; Freitas, Goi \& Giuliani, 2015; Frizzarini \& Cargnin, 2016); however, papers about teaching mathematics in higher education are scarce, and even scarcer for the graduate level.

One way by which teachers can come into accord with new teaching strategies is to look for further pedagogical development, such as attending specific courses for teaching to at least learn of new methodologies and how to apply them, because mathematics teachers at the undergraduate and graduate levels could start their courses using modern education methodologies to prepare students by learning within an active methodology.

The use of new educational technologies for teaching mathematics could represent a way, based on abstract, auditory, verbal, deductive and sequential analysis (Felder \& Silverman, 1988) to diminish student evasion of exacts courses (Ferreira, Silva \& Nunes, 2015) and attract those stimulated by those disciplines.

\subsection{Mathematical modeling}

The purpose behind using mathematical modeling in education has a recent history, however, in other conceptions it is linked to mathematical history because the use of modeling is intrinsically associated with the diary routines of ancient people (Biembengut \& Hein, 2009), such as the preparation for travel, for instance, which requires a previous established program, future previsions and a conception of route, and stops for food and drink etc.

The Mathematical Modeling methodology specifically originates from applied mathematics that was not used for teaching

initially (Frizzarini \& Cargnin, 2016). Different approaches have been subsequently proposed by mathematical education epistemology (Almeida, Silva \& Vertuan, 2013).

Important arguments justify the use of mathematical modeling courses in higher education and other levels of schooling (Almeida \& Silva, 2014). Examples, among others, include: (1) inclusion of extracurricular disciplines/knowledge in the course (i.e., a multidisciplinary approach); (2) applied math and the development of mathematical concepts; and (3) curricular integration of different disciplines (Frizzarini \& Cargnin, 2016).

The Mathematical Modelling method is applied between the identification of the initial problem and the final solution. In other words, it is the way to create proceedings and to obtain information in search for mathematical knowledge targeting a goal 
(Frizzarini \& Cargnin, 2016). In this way, the use of mathematical modeling in education is inserted in an active methodology if the student searches for a solution by their own reasoning.

The application of mathematical modelling in education began in the 1960's as a utilitarian movement (Biembengut, 2009), although it didn't begin in Brazil until the 1970's (Silveira et al., 2013). A landmark regarding teaching mathematical modeling in Brazil was the creation of a graduate course on the subject in 2001 and the creation of the Mathematical Modeling Working Group by the Brazilian Society of Mathematical Education (GT10) (Frizzarini \& Cargnin, 2016).

In 2007 the GT10 published the book "Modelagem Matemática na Educação Matemática Brasileira: Pesquisas e Práticas Educacionais" [Mathematical Modeling in Brazilian Mathematics Education: Researches and Educational Practices], indicating the following concentrations of mathematic modeling education: (1) theoretical aspects of mathematical modelling; (2) modeling and practice in the classroom to test strategies; (3) mathematical modeling and tendencies of information and communication; and (4) mathematical modeling and teacher development (Barbosa, Caldeira \& Araújo, 2007).

The GT10 published a second book about mathematical modeling in 2011, entitled "Práticas de Modelagem Matemática: Relatos de Experiencias e Propostas Pedagógicas" [Practices of Mathematical Modeling: Relates of Experiences and Pedagogical Proposes] (Almeida, Araújo \& Bisognin, 2011), which included an interdisciplinary proposal for biological phenomenon.

The use of mathematical modeling as a new teaching method in the classroom has existed for more than two decades, however, as happens with other fields of mathematical education, it has been scarcely explored in teaching, and mainly in undergraduate and graduate courses.

Indeed, the study of new methodologies in higher education is relatively new (D’Ávila, 2008; Pimenta \& Anastasiou, 2010; Garcia, 2013), with few papers addressing how to use new technologies in mathematics and correlated disciplines (Barros \& Sousa, 2015), mainly for undergraduate education.

Difficulty with adequately teaching mathematics is a challenge not yet overcome by teachers (Frizzarini \& Cargnin, 2016). It is a capital subject that directly involves educators and teachers and indirectly society (Rosa \& Orey, 2012). New proposals for teaching mathematics have not been completely implemented and must be tested at many levels of education (Almeida, Araújo \& Bisognin, 2011).

With regard to levels of education, for mathematics the most significant problem with using new technologies for teaching is probably at the undergraduate and graduate levels because pupils frequently arrive at universities with insufficient knowledge of the basis of mathematics.

This situation is worse if students have not attended any exacts courses. Accordingly, in order to improve mathematical reasoning by undergraduate students, a course of mathematical modeling was proposed for an Environmental Sciences graduate program.

The goal was to provide students the material needed to help them use mathematical models in their theses/dissertations. The students that attended the course came from biological programs and from biotechnology and environmental engineering, and thus had different levels of mathematical knowledge.

An unexpected occurrence during the second semester of the course in 2020, was the need to change to remote education due to the COVID pandemic. On the one hand, the experience made it more difficult, while on the other hand, it became more thought-provoking for both the teacher and the students.

Thus, the obligated remote study of a mathematical modeling course became an interesting experience to share, from the points of view of both students and teacher. In this way, this work aimed to analyze the use of the Mathematical Modeling 
Research, Society and Development, v. 10, n. 6, e2310615223, 2021

(CC BY 4.0) | ISSN 2525-3409 | DOI: http://dx.doi.org/10.33448/rsd-v10i6.15223

methodology in the course Applied Mathematical Modeling for Environmental and Biological Sciences, offered in an Environmental Sciences graduate (MSc and $\mathrm{PhD}$ ) program. The goal was to develop cognitive abilities and promote reflection, questioning and critical reasoning (Lupinacci \& Botin, 2004), and to provide students the ability to obtain their own knowledge (Ferreira, Silva \& Nunes, 2015), as useful skills for future scientists.

This work relates the perceptions of students and teacher about the aforementioned mathematical modeling course with partial use of active methodology and remote learning with intention to contribute to the mathematical education experience, for, at least, to identify some problems from the use of the active methodologies using the approaches of the Mathematical Modeling as an example for others studies.

\section{Material and Methods}

In this work, mainly, a qualitative approach was used to analyze the results. From responses from a questionnaire the objective questions were counted to verify the similarities of answers and the written responses were just considered for a subjective analysis.

Students were given a structured questionnaire (applied in the final of the course) and the opportunity to add spontaneous information about their experience in the course conducted from March to July of 2020 using active and traditional teaching.

The questions were:

1. What were reasons that led you to take the mathematical modeling course at PPGCA?

2. Did the change in teaching system, from classroom to remote study, change your enthusiasm to pursue the discipline? If possible, explain the reasons.

3. Have you had pedagogical training at undergraduate or graduate levels?

4. Are you aware of the teaching method called Active Methodologies? If so, write down your conception of it.

5. Do you believe that finding solutions to problems on your own can improve your learning? Please, if possible, explain.

6. Do you prefer traditional classes [teacher explaining with students studying for tests, activities] or looking for information on your own? Please explain.

7. Do you believe that remote study affected your learning in the mathematical modeling course?

8. Have you improved your knowledge of mathematical models and will you be able to apply one in your thesis/dissertation?

The responses were used to obtain the free expression of students about the course and its methodology. The active methodology was the students looking for information about the populational models and basic mathematical studies in group or individually for, after, to talk about those with the teacher.

The teacher of the course has degrees in Biology (bachelors), Civil Engineering and Mathematics (with pedagogical development) and some published papers about undergraduate teaching and education in the subjects of embryology, physiology, anatomy and civil engineering.

About course preparation, the syllabus/menu for the "Mathematical Models Applied to Environmental Sciences" course included: elementary notions of mathematics, functions, differential and integral calculus, definition of mathematical modeling, steps for constructing mathematical models, an example of application. These were separated into following three units:

Unit 1: Elementary Notions of Mathematics - operations, functions, limits, differential and integral calculus.

Unit 2: Mathematical Modeling - definitions, mechanical models, empirical models, semi-empirical models, steps for constructing mathematical models. 
Research, Society and Development, v. 10, n. 6, e2310615223, 2021

(CC BY 4.0) | ISSN 2525-3409 | DOI: http://dx.doi.org/10.33448/rsd-v10i6.15223

Unit 3: Applications of mathematical modeling - science in general, environmental sciences in particular.

The objectives in the syllabus/menu were: to provide students an integrated view of mathematical modeling, including theory and practice, in research in general, and in environmental sciences in particular.

The teaching methodology involved expositional classes with group discussions and active teaching proposals.

The methodology was altered because of the need for remote teaching after just one class. Subsequently, the teacher recorded classes for all the topics of the syllabus, which were made available on an internet channel, and online classes were held for 15 days. The university requested teachers to avoid online classes because of the difficulties that some students may have in accessing the internet and the possibility of signal loss during classes.

Most of the online classes involved students presenting papers about their master's or doctoral subjects. Time was provided during each class, before the presentation, to address any questions regarding the recorded classes or any other issue. The first class was used to explain the new methodology and that the active methodology would be used. A chat group and an e-mail address of the teacher were made available for students to solve doubts. Some classes and explanations about mathematical modeling were provided by the teacher, mainly for the topic of population modeling.

Student evaluation for the course was done via presentation of seminars and the completion of exercises about the populational models of the Malthus and Verhulst and their comparison. On the final day, a meeting was held with all students (just one absence), who students suggested scores according to the dedication of the course, which were averaged to generate the final score.

\section{Results}

\subsection{Students}

The course had 11 students, two of which did not respond to the questionnaire or write anything about the course - an Environmental Engineer and a mathematician.

In relation to first question [What were the reasons that led you to take the mathematical modeling course at PPGCA?], eight different answers were obtained with most students providing more than one. Three answered that teacher request was the reason; four to obtain more knowledge about the subject; one with the goal of obtaining autonomy in mathematical modeling; one because of difficulties in learning mathematics; four to write their thesis/dissertation according to the proposed project; one because there was no other mathematics course in the graduation program; one to complete the credits; and one because of similar purpose with an undergraduate course.

For the second question [Did the change in teaching system, from classroom to remote study, change your enthusiasm to pursue the discipline? If possible, explain the reasons], six responses were linked to diminished enthusiasm; three were linked to increased enthusiasm; and one responded as no change. Interestingly, two students responded increased enthusiasm on one hand, and diminished enthusiasm on the other. The main reasons for diminished enthusiasm were: difficulty with solving doubts (five students); lack of academic environment (three); problems with internet connection (two); absence of human interaction (two); many distractions at home (two); lack of exchange about experiences with colleagues [one]; and problems following the class calendar (one), increase of anxiety. Responses for increased enthusiasm were for distance between the university and home (around 100km) (one student) and the use of recorded classes for review (one), while only one student responded that there was no effect from the change from classroom to remote study. 
Research, Society and Development, v. 10, n. 6, e2310615223, 2021

(CC BY 4.0) | ISSN 2525-3409 | DOI: http://dx.doi.org/10.33448/rsd-v10i6.15223

Just one student responded to the third question [Have you had pedagogical training, at undergraduate or graduate levels?], as having had pedagogic training; one responded as attending a teaching course; eight responded that they hadn't had pedagogic training; and one was a university teacher but hadn't had pedagogic training.

To question four [Are you aware of the teaching method called Active Methodology? If so, write down your conception of it], six students responded NO; two responded YES; and one said they barely knew of Active Methodology. The student that attended a pedagogical course in biology and the university teacher were the only ones to give a correct conception of this methodology, namely that it was active action on behalf of the student in their learning.

To question number five [Do you believe that finding solutions to problems on your own can improve your learning? Please, if possible, explain], two students said they have difficulty learning on their own; five said that learning by themselves could be better; and two answered both, but depending on the circumstances. Those who responded NO indicated laziness; need for the teacher; preference for group studies; and it takes a long time to learn, as reasons for their choice. Those who responded YES indicated better criticism about the subjects and necessity to study more to learn. Those that responded BOTH, indicated the advantage of preparation for future work, however, one of them cited difficulties with learning on their own.

For question six [Do you prefer traditional classes [teacher explaining with students studying for tests, activities] or looking for information on your own? Please explain], three students indicated preference for traditional classes because of facilities for solving doubts and a better understanding of subjects when participating in classes; just one student considered active learning a challenge; five students chose BOTH, with traditional and active methodologies being used together, however, one indicated that traditional classes would be better for mathematics, while active methodologies would be better for other disciplines, while another indicated that it depends on the quality of the didacticism of the teacher, and for a "good" teacher the preference would be with traditional teaching.

Eight students responded negatively about their learning in response to question seven [Do you believe that remote study affected your learning in the mathematical modeling course?], while only one responded positively. The problems cited were fear of contact with the teacher; difficulties in solving doubts; other tasks disturbing the studies; and procrastination to study the discipline, while one said that they had problems, but not so much.

All responses to the last question, number eight [Have you improved your knowledge of mathematical models and will you be able to apply one in your thesis/dissertation?], were YES for improved knowledge. However, four of these students said they were incapable of generating a mathematical model for their scientific work, three said that were capable, and one did not respond to this part of the question.

Among the spontaneous responses, the main complaint (five responses) was with how the pandemic generated remote teaching. Other responses were suggestion for a list of exercises and weekly tasks (five) and request for more online meetings (1). As positive actions, the students cited that not only teaching of the logic of the calculus counts (2), importance of the review of basic mathematics classes (2), the opportunity of reflection on the subjects in the active methodology (2), discussion of articles about the field of each of the students (3), case study for mathematics modeling (2); and just one citation for each of the following themes: the WhatsApp group for discussion was a good idea; the system of self-evaluation; understanding of populational models; understanding of the types of models; understanding the growth of the pandemic via populational models; and the recorded classes available on the internet. 


\subsection{Teacher}

The proposed subjects of the course were presented in recorded classes and the presentation of seminars were one during the online classes with most of the students in attendance. Some loss of signal did indeed occur with some students housed far from urban centers. The students formed spontaneous study groups to study the recorded classes and work on the exercises about population models.

The menu of subjects was constructed to generate a basis for understanding population models with preparation exercises in the classes, however, many problems in understanding how to resolve the exercises occurred. Solving the exercises required looking for data from a real population and to organize to use a formula, which was the main difficulty. Most students showed good attention to the mathematical explanation of exponential and logarithmic functions linked to real examples.

One of the objectives was to demonstrate, in detail, the origin of the equations of the Malthus and Verhulst models, however, difficulties for students permitted just a partial demonstration. Indeed, most of the students were biologists, while there were three environmental engineers, one economist, one mathematician and one biotechnologist. All of students had some difficulties with mathematical thinking, with no one correctly resolving of proposed exercise, which was a trivial one.

The seminars were well-presented by the students, yet with some difficulties about mathematical subjects. In the selfevaluation, with just one absence, all students cited the delay in following the classes and difficulties in understanding how to resolve the proposed exercise.

As cited by students, the change of kind of teaching due the pandemic generates some problems for the student's adaptation, mainly in relation to the reader and to interpretate the texts for looking for the self-apprenticed.

\section{Discussion}

According to the results of the present study, most of the students expressed dissatisfaction with the change from presentational teaching to remote classes. The students, in general, preferred the presence of the teacher in traditional classes and, interestingly, felt ashamed to contact the teacher via social media.

According to their responses, three students took the course at the request of their advisor and/or to complete credits. These are not good reasons to take a course and may make it difficult to implant new methodologies because such students have not sought the discipline by themselves. The reason most of the students gave for attending the course was a desire to learn about mathematical modeling in particular, and mathematics in general, for use in their papers and thesis/dissertations and that searching for mathematical models is an interesting subject. Although these responses indicating an appreciation of the importance of this subject in modern science, the teacher observed that most of the students had no complete idea about the subject.

Most students cited a loss of motivation with the change from traditional to virtual classes and gave several reasons. This is a strong indication that the new methods used presented some difficulties in teaching that need to be addressed (Onuchi \& Morais, 2013), at least for this discipline.

Only one student had some educational training, and less than half knew about active methodologies, which could be the reason for the cited difficulty with inserting mathematical modeling in this course, and the main cause could be that traditional teaching is ingrained in the lives of students (Alves \& Aversi-Ferreira, 2019).

Indeed, all students showed some dissatisfaction with active methodologies and anxiety about solving practical problems from theory, probably because of learned behavior from a long time under traditional teaching (Alves \& Aversi-Ferreira, 2019). 
Problems were shown in the recorded classes and solved by the teacher, but a list of exercises was not presented, just indications for studies in books.

According to the thinking of the teacher, master's and doctoral students must show some facility of obtaining knowledge from texts, since the disciplines were studied prior to graduate school. Indeed, biological courses, in general, present mathematic in their syllabus. However, the basic mathematical knowledge was not detected among most of the students, including an environment engineer.

All of the students understood the need to study and solve problems by their own effort, but the teacher felt that the absence of a structured algorithm and model that indicate a similar response for the proposed exercises was the main cause of difficulty. In other words, the students have a need for solved examples to direct solutions of other problems, in which case the teacher solves problems and provides an exercise list with similar problems.

In such a case, there is incoherence between necessity and behavior. Thinking indicates the best way to learn, however, the long history of traditional practices seems to overcome reasoning.

This kind of situation generally comes from the mistaken interpretation of teaching methods and the heritage of the German method (Theory of Mental Discipline) based on a long list of problems, such as training to solve problems by emphasizing final results and not the process (Onuchic \& Morais, 2013), which has, until now, been used in Brazil (Belhot \& Oliveira Neto, 2006).

On the other hand, some students cited difficulty with learning alone, that is, in the absence or far from the teacher. This could be explained by social-historical-cultural psychology theory that preconizes the influence of the environment on the development of the mind and cognitive processes (Luria, 1937; Vygotsky, 1991), which is one more example of conditioned behavior.

An unexpected situation was that all students complained verbally about the time dedicated to the course because of an excess of tasks from other classes, probably because, in response to the implementation of remote studies, teachers sent too many tasks. It was interesting, however, that the students did not complain about this in the free text.

It is also interesting that limited time is one of the cited problems for implementing mathematical modeling and problems solving in teaching, according to Ferreira, Silva and Nunes (2005).

According to the perceptions of the students and the teacher about the mathematical modeling course, the students had problems accepting remote studies and active teaching methodologies, as cited by Beholt and Oliveira Neto (2006).

The teacher observed difficulties with basic mathematics, which is a common problem in Brazil (Alves \& Aversi-Ferreira, 2019). This may have generated the dissatisfaction in solving the problems because of the comfort the students had with the longtaught traditional teaching and the very strong needs for the use of identical model problems for the application of algorithms, thus decreasing the effort to solve other problems.

\section{Conclusions}

The teacher and students believe there is a need for detailed explanations of new methodologies for students in the initial first class to obtain adherence to an active methodology of teaching. The implementation of mathematical modeling did take place, but it was not totally successful, mainly because:

1. The drastic change from normal (traditional) to virtual (remote) classes.

2. The lack of student experience with mathematical modeling and problem solving.

3. Student preference for the presence of the teacher in normal classes. 
Research, Society and Development, v. 10, n. 6, e2310615223, 2021

(CC BY 4.0) | ISSN 2525-3409 | DOI: http://dx.doi.org/10.33448/rsd-v10i6.15223

4. Student need for training with solved exercises similar to those of a list of exercises for them to solve on their own.

5. The difficulty students have with learning on their own.

6. The difficult the teacher has with perceiving student difficulties because of virtual classes.

Challenges cited by other authors, such as limited time and a culture engrained in traditional teaching, were also observed in the present work, indicating the need to introduce mathematical modeling and problem solving in the initial phases of teaching mathematics.

Additional works considering the practical experiences among students and teachers could be performed to generate more information about the problems found in using the activities methodologies, mainly using the classes experiences.

\section{Acknowledgements}

The authors thank to anonymous reviewers by the comments that increase the quality of this manuscript.

\section{References}

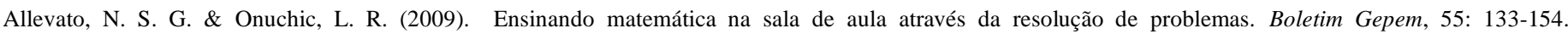
costalima.ufrrj.br/index.php/gepem/article/download/77/228\#page $=131$

Almeida, L. W.; Silva, K. P. \& Vertuan, R. E. (2012). Modelagem Matemática na educação básica. Contexto.

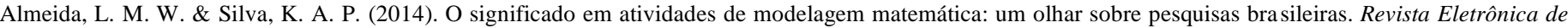
Educação Matemática, 9:124-145. https://periodicos.ufsc.br/index.php/revemat/article/viewFile/1981-1322.2014v9nespp124/27397

Almeida, L. M. W.; Araújo, J. L. \& Bisognin, E. (2015). Práticas de modelagem matemática: relatos de experiências e propostas pedagógicas. Eduael.

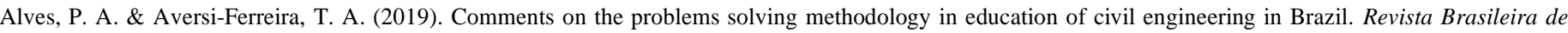
Ensino de Ciência e Tecnologia, 12: 134-53.

Barbosa, J. C.; Caldeira, A. D \& Araújo, J. (2007). Modelagem matemática na educação matemática brasileira: pesquisas e práticas educacionais. Sbem.

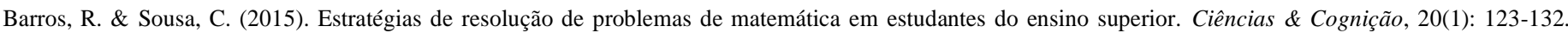
http://www.cienciasecognicao.org/revista/index.php/cec/article/download/1000/pdf_55

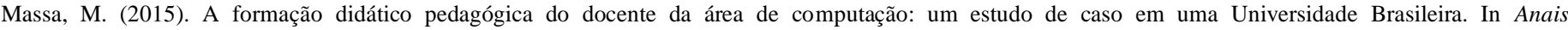
do XXIII Workshop sobre Educação em Computação, (pp. 196-205). SBC. 10.5753/wei.2015.10236

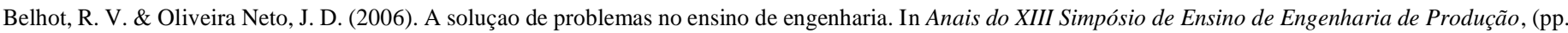
1-9). Bauru: UNESP.

Belloni, M. L. (2008). Educação à distância. Autores Associados, 2008.

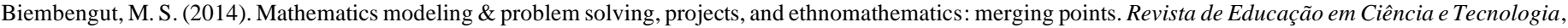
7(2):197-219. https://hal.archives-ouvertes.fr/hal-01287247/document

Biembengut, M. S. \& Hein, N. (2009). Modelagem matemática no ensino. Contexto.

Burak, D. \& Kluber, T. E. (2008). Educação matemática: contribuições para a compreensão de sua natureza. Acta Scientiae, $10,93-106$.

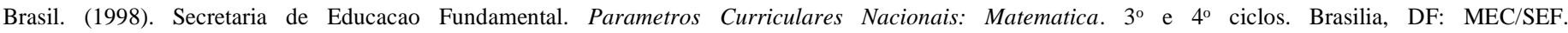
http://portal.mec.gov.br/seb/arquivos/pdf/matematica.pdf.

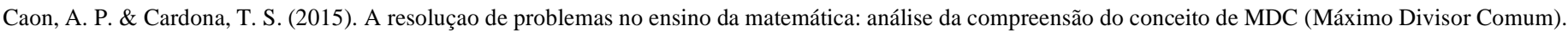
In anais do VII Encontro Mineiro de Educação, (pp.1-5). UFU.

Carraher, T. N. (1986). Aprender pensando: contribuições da psicologia cognitiva. Vozes.

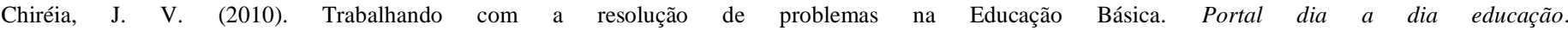
http://www.diaadiaeducacao.pr.gov.br/portals/pde/arquivos/74-4.pdf

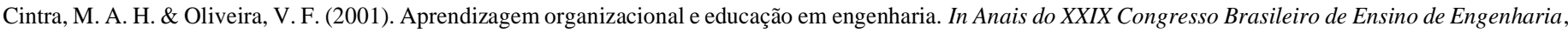
(pp. 1-7). ABENGE. 
Research, Society and Development, v. 10, n. 6, e2310615223, 2021

(CC BY 4.0) | ISSN 2525-3409 | DOI: http://dx.doi.org/10.33448/rsd-v10i6.15223

Clement, L. \& Terrazzan, E. A. (2011). Atividades Didáticas de Resolução de Problemas e o Ensino de Conteúdos Procedimentais. Revista electrónica de investigación en educación en ciencias, 6(1): 87-101. https://dialnet.unirioja.es/descarga/articulo/4460252.pdf

D’ Ambrósio, U. (2008). Educação matemática: da teoria à prática. Papirus.

D’ Ambrósio, U. (1998). Etnomatemática: arte ou técnica de explicar e conhecer. Ática.

Dante, L. R. (1998). Didática da resolução de problemas de matemática. Ática.

D’Avila, C. (2008). Formação docente na contemporaneidade: limites e desafios. Revista FAEEBA, 17(30): 33-41. https://www.revistas.uneb.br/index.php/faeeba/issue/view/227

Faccin, E. L. (2018). Modelagem matemática na dinâmica de MEMS baseados em deformação elástica utilizando modelos polinomiais contínuos, Novas Edições Acadêmicas.

Felder, M. \& Silverman, L. K. (1998). Learning and teaching styles in engineering education. Engineering education, Oxfordshire, 78(7): 674-681. https://www.academia.edu/download/31039406/LS-1988.pdf

Fernandes, C. M. B. (1998). Formação do Professor Universitário: tarefa de quem? In Masetto, M. (Eds). Docência Universitária. (1998). Papirus.

Ferraz, H. (1983). A formação do engenheiro: um questionamento humanístico. Ática.

Ferreira, L. L.; Silva, L. B. \& Nunes, C. B. (2015). O ensino da matemática através da resolução de problemas no curso de engenharia civil. In Anais do VII Encontro Mineiro de Educação Matemática, (pp. 1-5).: UFU.

Freitas, J. Q. P.; Goi, M. E. J. \& Giullianni, O. F. (2015). Resolução de problemas no ensino da matemática: Uma Introdução à Geometria Fractal no Ensino Fundamental. Degree in Exact Sciences dissertation, UNIPAMPA.

Frizzarini, S. T. \& Cargnin, C. (2016) Prática de ensino: modelagem matemática e resolução de problemas. UniCEsumar.

Garcia, C. M. (2013). Formação de professores: para uma mudança educativa. Porto Editora.

Godoy, A. S. (1983). Professor universitário da área de agronomia: o problema na formação pedagógica. Master dissertation, University of São Paulo. Brazil.

Groenwald, C. L.; Silva, C. K. \& Mora, C. D. (2004). Perspectivas em Educação Matemática/Perspectives in Mathematics Education. Acta Scientiae, 6(1): $37-56$.

Lesh, R. \& Zawojewski, J. S. (2007). Problem solving and modeling. In Lester, F. (Eds). Second handbook of research on mathematics teaching and learning, information age publishing (pp. 763-802). CT.

Lester, J. \& Koehler Jr, W. C. (2003). Fundamentals of information studies: understanding information and its environment. New York, NY: Neal-Schuman Publishers.

Lima, S. S. \& Alves Neto, F. R. (2015). Desafios na prática pedagógica do docente iniciante em instituições de ensino superior. Revista Saberes FAMETA, 2: 1-10. Retrieved from https://unimeta.edu.br/por-que-a-fameta/revista-saberes/edicao-2/

Lupinacci, M. L. V. \& Botin, M. L. M. (2004). Resolução de problemas no ensino de matemática. In Anais do VIII Encontro Nacional de Educação Matemática, (pp. 1-5). Recife: UFPE.

Luria, A. R. (1937). The working brain: an introduction to neuropsychology. Basic Books.

Machado, L. J. (1987). Matemática e realidade: análise dos pressupostos filosóficos que fundamentam o ensino de matemática. Cortez.

Mansfield, D.F. \& Wildberger, N. J. (2017). Plimpton 322 is babylonian exact sexagesimal trigonometry. Historia Mathematica, 44(4): 395-419. doi.org/10.1016/j.hm.2017.08.001

Massa, M. (2015). A formação didático pedagógica do docente da área de computação: um estudo de caso em uma Universidade Brasileira. In Anais do XXIII Workshop sobre Educação em Computação, (pp. 196-205). Porto Alegre: SBC. 10.5753/wei.2015.10236

Mendes, I. A. (2009). Matemática e investigação em sala de aula: tecendo redes cognitivas na aprendizagem. Livraria da Física.

Moraes, M. C. \& Torres, S. (2004). Sentipensar: fundamentos e estratégias para reencantar a educação. Vozes.

Nosella, P. (2004). Trabalho e educação: do tripalium da escravatura ao labor da burguesia à poiésis socilista. In Gomez, C. M. (Eds). Trabalho e conhecimento: dilemas na educação do trabalhador (pp. 27-41). Cortez, 2004.

Onuchic, L. R. (2013). A resolução de problemas na educação matemática: onde estamos? E para onde iremos? Revista Espaço Pedagógico, 20(1): 88-104. http://seer.upf.br/index.php/rep/article/download/3509/2294/

Onuchic, L. R. \& Morais, R. S. (2013). Resolução de problemas na formação inicial de professores de matemática. Revista do Programa de Estudos Pós-Graduados em Educação Matemática, 15(3): 671-691. https://revistas.pucsp.br/emp/article/download/16951/pdf

Piaget, J. \& Beth, E.W. (1980). Epistemologia matemática e psicologia. Crítica S.A. 
Research, Society and Development, v. 10, n. 6, e2310615223, 2021

(CC BY 4.0) | ISSN 2525-3409 | DOI: http://dx.doi.org/10.33448/rsd-v10i6.15223

Pimenta, S. \& Anastasiou, L. (2010) Docência no ensino superior. Cortez.

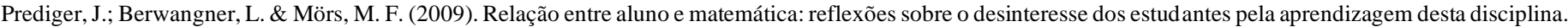
Revista Destaques Acadêmicos, 1(4). http://www.univates.com.br/revistas/index.php/destaques/article/viewFile/39/37

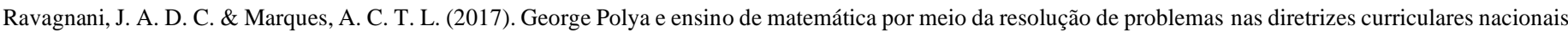

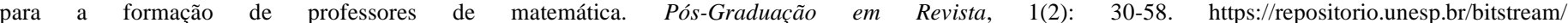
handle/11449/102122/nunes_cb_dr_rcla.pdf?sequence=1

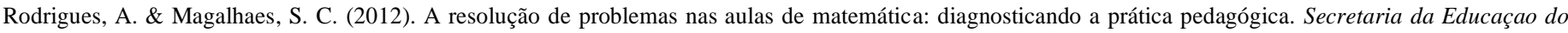
Estado do Paraná. http://www.educadores.diaadia.pr.gov.br/arquivos/File/setembro2012/matematica_artigos/artigo_rodrigues_magalhaes.pdf

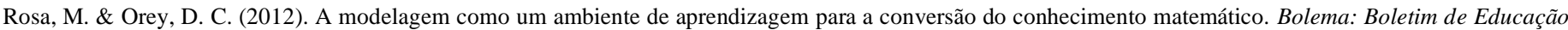
Matemática, 26(42a), 261-290. https://dx.doi.org/10.1590/S0103-636X2012000100012

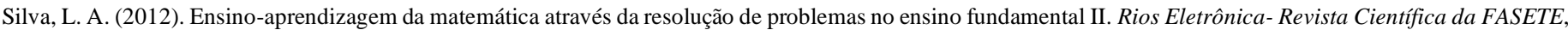
6(6): 49-55. https://www.unirios.edu.br/revistarios/internas/conteudo/?id=8

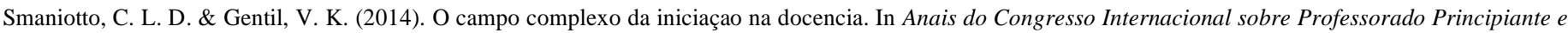
Inserção Profissional à Docencia. (pp. 134-153). Curitiba: UFPR.

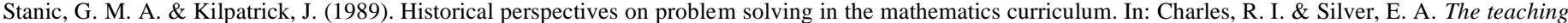
and assessing of mathematical problem solving (pp. 1-22). Reston, VA: NCTM/Lawerance Erlbaum Associates.

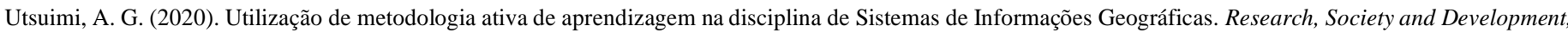
9(7), e904975014. http://dx.doi.org/10.33448/rsd-v97.5014

Vygotsky, L. S. (1991). A Formação social da mente: o desenvolvimento dos processos psicológicos superiores. Martins Fontes, 1991. 